Kansas State University Libraries

New Prairie Press

International Symposium for Innovative

2017 International Symposium on Innovative

Teaching and Learning

Teaching and Learning

\title{
Adding the Learners' Perspective to Language Teaching
}

Abby Franchitti

Kansas State University, abbyfran@ksu.edu

Follow this and additional works at: https://newprairiepress.org/isitl

cc) (i) (2)

This work is licensed under a Creative Commons Attribution-Noncommercial-Share Alike 4.0

License.

Recommended Citation

Franchitti, Abby (2017). "Adding the Learners' Perspective to Language Teaching," International Symposium for Innovative Teaching and Learning. https://doi.org/10.4148/2573-4911.1015

This Poster is brought to you for free and open access by the Conferences at New Prairie Press. It has been accepted for inclusion in International Symposium for Innovative Teaching and Learning by an authorized administrator of New Prairie Press. For more information, please contact cads@k-state.edu. 


\section{Adding the Learners' Perspective to Language Teaching:}

\section{Non Native English Speakers Teaching English - Perceptions, Observations, and Strategies}

Revised from TESOL Pre conference session, Toronto, March 2015

Abby Franchitti, Ph.D

English Language Program

Kansas State University

abbyfran@ksu.edu 
Non Native English Speakers Teaching

English

- The Teaching English as a Second or Other Language organization initiatives

- Some history

- The disappointment:

Survey: feedback and comments

- The issues and obstacles

- Analysis

- Opportunities

- Strategies

- References 


\section{The TESOL initiative}

Due to discrimination against NNESTs

In 1991

- TESOL adopted a resolution of disapproval of discriminatory hiring policies

- TESOL decided to take steps to abolish all forms of restriction based on the applicant's native language 


\section{The Organization creates a}

\section{forum: TESOL Interest Section:}

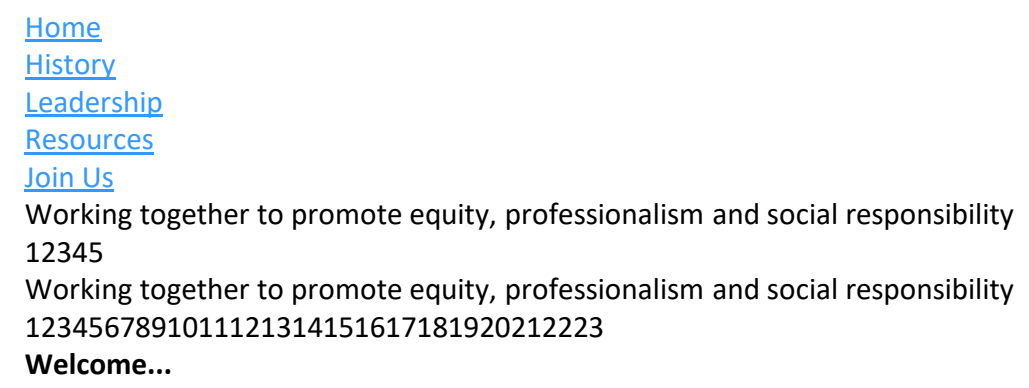

The Nonnative English Speakers in TESOL (abbreviated as 'NNEST' and pronounced as /عn'nest/ or en-nest) Interest Section serves as a focus for the interaction of members who share a common interest in a wide variety of issues concerning native and non-native English-speaking professionals in TESOL. It creates a venue for identifying and addressing NNEST-related issues and faciliating communication and networking both among IS members and those of TESOL at large.

- The Interest Section aims to

- Promote, develop, and advance academic and professional awareness of the role of NNEST professionals in the field

- Stimulate scholarship, research, and professional development by sponsoring special projects, sessions at the TESOL Convention, and publications

- Create a nondiscriminatory professional environment for all TESOL members regardless of native language, race, and place of birth

- Enhance and empower the professional growth of its members

- Serve as an advocate and resources for NNEST communities and individuals in professional matters

- Being one of the most diverse of all interest sections within TESOL International Association, the NNEST Interest Section (NNEST IS) is the institutionalized home base and the intellectual space of the NNEST movement. The establishment and activities of the NNEST IS spearheaded the formation of other NNEST-related entities within local TESOL affiliates including the WATESOL's (Washington Area TESOL) NNEST Caucus, and the CATESOL (California TESOL) NNLEI-Nonnative Language Educators Interest Group.

- Awareness and Advocacy

- NNEST IS promotes awareness and advocacy among all TESOL professionals.

- $\quad$ Equity and Professionalism for All

- $\quad$ NNEST IS prioritizes such values as collaboration, participation, equity, justice and professionalism

- Moving beyond Discrimination

- NNEST IS aims to build a non-discriminatory professional environment for all TESOL members regardless of native language, race, ethnicity, gender, religion and place of birth.

- $\quad$ C 2017 | Created by Ali Fuad Selvi for the NNEST Interest Section

Hosted by Lucie Moussu 


\section{Did you know?}

\section{NNEST History}

- $\quad$ First proposed in 1996 and officially established as one of the six caucuses in TESOL International Association in 1998, NNEST Caucus transformed itself into an 'Interest Section' status in 2008. Since then, it has been the institutionalized home base and the intellectual space of the NNEST movement.

\section{- The Birth and Rise of the NNEST Movement}

- Although critical scholarship focusing on NNEST issues began to gain attention in 1990s, the formal beginnings of the NNEST movement dates back to the colloquium entitled "In Their Own Voices: Nonnative Speaker Professionals in TESOL", organized by George Braine at the 30th Annual TESOL Convention held in Chicago in 1996. The colloquium brought together both leading and emerging NNS scholars in TESOL/applied linguistics, including Ulla M. Connor, Suresh Canagarajah, Kamal Sridhar, Jacinta Thomas, and Devi Chitrapu. The idea for a brand new Caucus focusing on NNEST issues emerged at the discussion and was followed up by a signature drive.

- In 1998, the Non-Native English Speakers in TESOL (NNEST) Caucus was formally established with George Braine as the Chair, Jun Liu as the Chair-elect, Lia Kamhi-Stein as the Newsletter Editor, and Aya Matsuda as the Webmaster. The first official meeting of the Caucus was held at the 1999 TESOL Convention in New York.

- The overarching goal of the Caucus was basically to strengthen effective teaching and learning of English around the world while respecting individuals' language rights. More specifically, the primary goals of the Caucus were to

- create a nondiscriminatory professional environment for all TESOL members regardless of native language and place of birth

- encourage the formal and informal gatherings of NNS at TESOL and affiliate conferences

- encourage research and publications on the role of nonnative speaker teachers in ESL and EFL contexts, and

- promote the role of nonnative speaker members in TESOL and affiliate leadership positions.

- In 2008, by consensus of its members, the Caucus transformed itself into an Interest Section of the TESOL organizations. This may be regarded as a step forward since Caucuses are primarily advocacy-oriented whereas Interest Sections deal more in-depth with professional issues. In the meantime, the establishment of an NNEST-related entity was echoed in local TESOL affiliates through the foundation of the CATESOL (California TESOL) NNLEI Group (1999), and WATESOL (Washington Area TESOL) NNEST Caucus (2004).

- $\quad$ Serving as the institutionalized home base and the intellectual space of the NNEST movement ever since, the NNEST Caucus/Interest Section created a biannual newsletter, an active listserv, and the website to publicize its activities and disseminate information among the membership. Today, it is home to an extremely diverse and vibrant TESOL community striving for such values as collaboration, participation, equity, justice and professionalism in TESOL.

- Here are three articles by our former presidents, George Braine and Brock Brady, which take us through the journey of how the NNEST Caucus came to exist:

- $\quad$ NNS and Invisible Barriers in ELT Non-native English Speakers in TESOL Caucus Formed Growing Recognition - The New Non Native English Speaking Teaching Interest Section

- $\quad$ C 2017 | Created by Ali Fuad Selvi for the NNEST Interest Section Hosted by Lucie Moussu 


\section{The disappointment}

Despite advocacy, the situation seems to have evolved very slowly since 1991.

Email survey sent out over several listservs gave the following results:

Percentage of non-native speakers to

native English language speakers

ranged from $0.5 \%$ to $15 \%$

Skills taught ranged from no oral

communication skills to anything the instructor felt comfortable teaching 


\section{Feedback:}

Under representation is often due to:

- Colleagues perception despite administration's policy

- Hiring criteria

- Prevailing wage and H1B visa sponsorship

- OPT requirements

- Red tape/ Time

Comments:

- Not too much of an issue because

- the native speakers tend to teach in ESL environments

- non-native speakers teach in EFL environments

- A minor problem

- Not worthy of a study or a response

- We don't hire them

- We restrict their teaching assignments

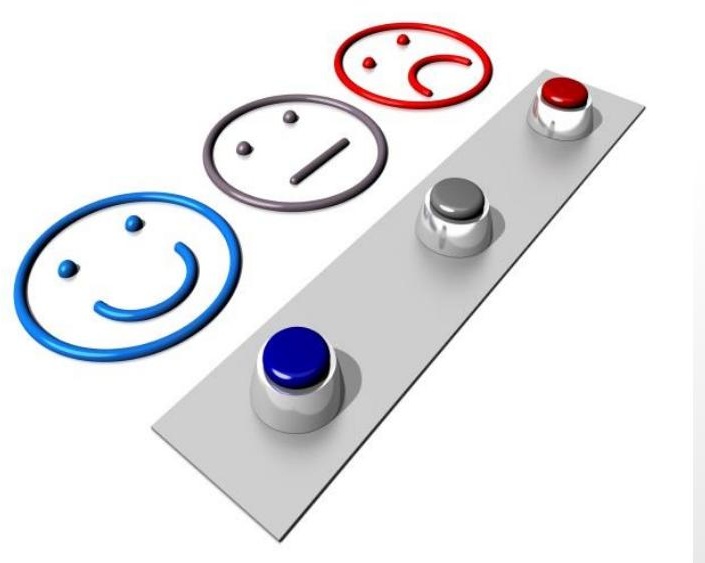




\section{The issues and obstacles:}

Issues

- Communication

- Pronunciation

- Accent

- Linguistic competency

- Pedagogy

- Experience

Obstacles

- Self perceptions

- Perceptions of others

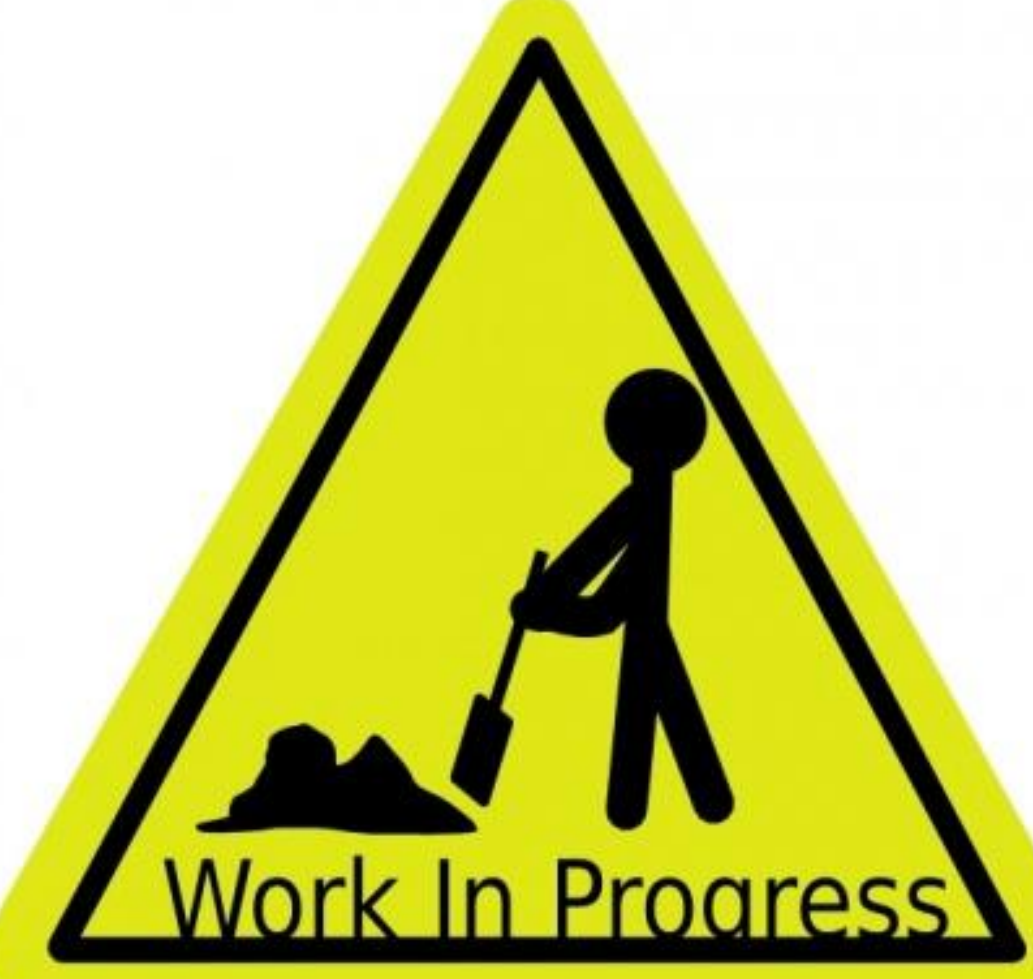




\section{Perceptions matter}

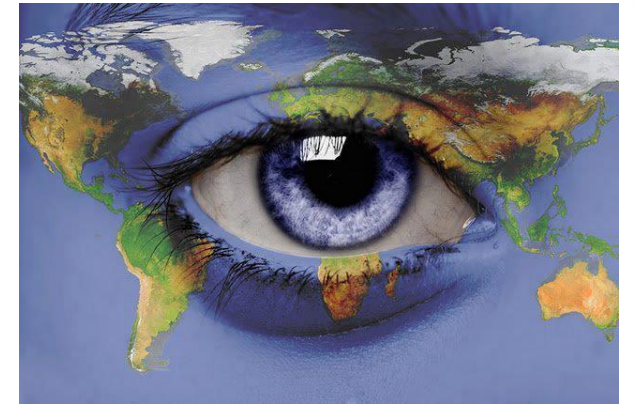

Self perceptions

have not changed:

- Linguistic handicap: vocabulary; idiomatic expressions, spontaneity, comfort, and ease

- Deficiency in fluency, pronunciation, and listening

- Perception of being not as proficient

- Double role as teacher and learner

Perceptions of others can be negative:

- "Give me a teacher with a British/American accent."

- Colleagues perceptions are negative despite administration policy

- Native speakers are more fluent

- Native speakers know the language and idioms better

- Native speakers are better models

- Non native speakers make mistakes 


\section{Opportunities exist:}

\section{Countries to Teach English Abroadas a Non NativeSpeaker?}

May 29, 2017/Megan Lee

- So you may not be from the USA, the UK, Australia, or any other of the countries deemed as home to "Native English Speakers," but you still want to teach abroad. The good news? You absolutely can teach English abroad as a nonnative speaker.

- The slightly-bummer news? Your job options will be slightly more limited (particularly in East Asia and the Persian Gulf countries), and you might have to take some extra steps in the application process to prove your qualifications.

- Those small details aside, there is still plenty of teach abroad opportunities from our friends who - like their students - speak English as a second language.

- And that's just it, isn't it? You've literally studied the language, know the in's and out's and the rules and exceptions and *gasp* - even how to explain them.

- As an ESL student yourself, you have years of experience tackling the beast that is English fluency, and have inside intel on what works for a lesson plan and what usually falls flat. And as far as we're concerned, that makes you an ESL teacher more students can relate to a teacher who isn't afraid to empathize with the struggle, and a teacher who is more motivated than ever to help non-native speakers achieve your level of proficiency (or more!).

- https://premiertefl.com/2017/05/5-countries-to-teach-english-abroad-as-a-nonnative-speaker/ 


\section{Strategies to Enrich Teaching and Learning}

- Identifying what makes Non Native Teachers different and what specific teaching strategies they use to teach.

- Identifying the ways these strategies are similar to or different from the strategies Native Speakers use to teach the language.

- Identifying how Non Native speakers' learning experience has enriched their teaching experience and practice.

- Communication with Native Speakers about Teaching and Learning: creating a dialogue and exchange

- Collaboration between Native Speakers and Non Native Speakers by creating a Teaching Team to share teaching techniques and learning strategies to enhance learners' experiences and teaching 


\section{References}

- Native or non-native English speaker - is it important when teaching English?This entry was posted in Teaching English abroad tefl blog TEFL courses and tagged teaching english teaching english abroad teaching english in spain tefl courses on September 16, 2013 by Jim Ross (EBC TEFL course).file:///C:/Users/abbyfran/Desktop/Native\%20or\%20non-

native\%20English\%20speaker.\%20Important\%20for\%20teaching\%20English\%20.htm

- "Perceptions of NNESTs";Beverly Hartford, Ahmar Mahboob, Karen Newman, and Karl

Uhrig,hartford@indiana.edu, amahboob@indiana.edu, klnewman@indiana.edu,

kuhrig@indiana.edu,Presented at TESOL 2002, Salt Lake City, UT,Indiana University

- The Non-Native Teacher, by Peter Medgyes

- Keiko SamimyTESOL Quarterly

Vol. 31, No. 4 (Winter, 1997), pp. 815-817

Published by: Teachers of English to Speakers of Other Languages, Inc. (TESOL)

Article Stable URL:http://www.jstor.org/stable/3587770

- When the teacher is a non native speaker, Peter Medgyes,

http://teachingpronunciation.pbworks.com/f/When+the+teacher+is+a+non-native+speaker.PDF

- http://nnest.moussu.net/history.html

- https://www.i-to-i.com/tefl-blog/expert-tefl-advice/can-i-teach-abroad-if-not-a-native-speaker/

- https://www.britishcouncil.org/voices-magazine/native-english-speaking-teachers-always-right-choice

- https://www.teachingtraveling.com/2016/05/23/non-native-english-speaker/

$\bullet$

- https://premiertefl.com/2017/05/5-countries-to-teach-english-abroad-as-a-non-native-speaker/

- http://nnest.moussu.net/index.html 